\title{
Effect of cryoprotectants on the survival of follicles in frozen mouse ovaries
}

\author{
C. J. Candy, M. J. Wood* and D. G. Whittingham \\ Department of Anatomy and Developmental Biology, St George's Hospital Medical School, \\ Cranmer Terrace, London SW17 ORE, UK
}

\begin{abstract}
Ovaries from 10-day-old mice were exposed to $1.5 \mathrm{~mol} 1^{-1}$ dimethylsulfoxide, 1,2propanediol, ethanediol or glycerol for 5-60 $\mathrm{min}$ at room temperature before freezing. Follicles in fresh and frozen ovaries were counted and scored as normal or damaged in stained serial sections. More primordial follicles survived in ovaries frozen in dimethylsulfoxide, 1,2-propanediol and ethanediol (81-94\%) than in those frozen in glycerol (4-28\%). Prolonged exposure to ethanediol $(60 \mathrm{~min})$ before cooling decreased the survival rate, while increasing the exposure to glycerol ( $\geq 12 \mathrm{~min}$ ) increased the survival rate. Fewer than $49 \%$ of primary follicles survived freezing. After transfer underneath the kidney capsules of ovariectomized immunodeficient recipients, there was no difference in the establishment of grafts of fresh $(92 \%)$ and frozen $(90 \%)$ ovaries, the number of recipients showing vaginal cornification (fresh, 91\%; frozen, 96\%) or the latency of cornification (11 days). Fifteen days after transplantation, similar numbers of follicles remained in grafts of fresh ovaries, in ovaries frozen in dimethylsulfoxide and 1,2-propanediol, and in ovaries frozen after exposure to ethanediol for 5-30 min. Overall, the total number of follicles remaining in grafts of ovaries frozen in dimethylsulfoxide and 1,2-propanediol represented $42-46 \%$ of follicles present in ungrafted ovaries. This was not significantly different from grafts of fresh ovaries (63\%). Dimethylsulfoxide and 1,2-propanediol are the most effective cryoprotectants for 10-day-old mouse ovaries. The majority of follicles are lost during graft establishment.
\end{abstract}

\section{Introduction}

The ability to cryopreserve the female gamete has important applications for the clinical treatment of infertility and for the conservation of endangered species. Cryopreservation of ovarian tissue would enable the storage of large numbers of primordial follicles and preserves the structural integrity of somatic and reproductive cells within the ovary. Ovarian tissue of rat, mouse, sheep, human and marmoset has been frozen successfully. Grafts of frozen mouse (Harp et al., 1994) and rat (Parkes and Smith, 1953) ovaries have restored cyclic function in ovariectomized recipients. Similarly, there is a report of cryopreserved human ovarian tissue, transplanted subcutaneously, restoring the menstrual cycle in women (Grischenko et al., 1987). Large antral follicles developed in xenografts of cryopreserved marmoset ovary (Candy et al., 1995a). Live young were born after orthotopic transplantation of cryopreserved ovarian tissue from mice (Parrott, 1960; Cox et al., 1996) and sheep (Gosden et al., 1994). In spite of these successes, a large proportion of follicles is damaged during freezing and thawing. Mouse (Deanesly, 1957) and rat (Green et al., 1956) ovarian tissue frozen using glycerol as the

*Correspondence.

Received 12 September 1996. cryoprotectant was estimated to contain $<10 \%$ of morphologically normal follicles. A higher proportion of follicles (33\%) survived in marmoset ovarian tissue cryopreserved with dimethylsulfoxide (Candy et al., 1995a). Some primordial and primary follicles in human ovarian tissue have survived freezing in dimethylsulfoxide, ethanediol, 1,2-propanediol and glycerol (Hovatta et al., 1996; Newton et al., 1996).

Methods developed for freezing isolated mature mouse oocytes (Carroll et al., 1993) have been used to freeze ovarian tissue. These techniques have also been used successfully for the cryopreservation of immature mouse oocytes (Candy et al., 1994), and isolated primordial (Carroll and Gosden, 1993) and primary (Carroll et al., 1990) follicles. However, they may not be optimal for the cryopreservation of ovarian tissue since the ovary is a complex structure comprising many different cell types and containing follicles at various stages of folliculogenesis.

In this study, we examined two parameters of cryopreservation that may affect the survival of follicles in the mouse ovary; namely, the type of cryoprotectant used and the duration of exposure to the cryoprotectant before cooling. Survival of follicles was assessed immediately after thawing and after transplantation underneath the kidney capsules of ovariectomized recipients. We report the successful cryopreservation of mouse ovaries as shown by the survival of high 
proportions of primordial follicles in thawed ovaries, and the development of large numbers of follicles at all stages of folliculogenesis in frozen ovaries after grafting to recipients. Preliminary reports of these data have appeared elsewhere (Candy et al., 1995b; Wood et al., 1995).

\section{Materials and Methods}

Except where stated, all manipulations were carried out in Hepes-buffered M2 medium (Wood et al., 1987) in which the BSA was replaced with $10 \%$ fetal bovine serum (FBS; ICN Flow, High Wycombe) at $37^{\circ} \mathrm{C}$.

\section{Ovarian tissue}

Ovaries from 10-day-old B6CB (C57BL/6JLac $\times$ CBA/CaLac) F1 hybrid mice were dissected free of fat and mesentery. Intact ovaries (approximately $2 \mathrm{~mm}^{3}$ ) were frozen, transplanted underneath the kidney capsules of recipient mice or placed in Bouin's fixative for histology within $30 \mathrm{~min}$ of dissection. Intact ovaries from adult (57-day-old) B6CBFI mice were fixed for histology immediately after dissection.

\section{Freezing and thawing}

Four cryoprotectants were compared in this study: dimethylsulfoxide (DMSO; BDH Ltd, Poole); 1,2-propanediol (PROH; Sigma Chemical Co., Poole); ethanediol (EG; Sigma Chemical Co.) and glycerol (GLY; BDH). Ovaries were placed in $1-2 \mathrm{ml}$ of $1.5 \mathrm{~mol}$ cryoprotectant $1^{-1}$ in $\mathrm{M} 2$ and held at room temperature (about $20^{\circ} \mathrm{C}$ ) for $5,12,30$ or $60 \mathrm{~min}$ before being loaded into $1.8 \mathrm{ml}$ cryovials (Nunc Intermed, Kamstrup; 1-3 ovaries per vial) in $0.3 \mathrm{ml}$ of the same solution. The cryovials were placed in a programmable freezer (R202; Planer Biomed, Sunbury-on-Thames) at $0^{\circ} \mathrm{C}$ and cooled at a rate of $2^{\circ} \mathrm{C} \min ^{-1}$ to $-8^{\circ} \mathrm{C}$. Ice crystal nucleation was initiated at the meniscus of the cryoprotectant solution $5 \mathrm{~min}$ later by touching the side of the cryovial with precooled forceps. After a further $5 \mathrm{~min}$, the cryovials were cooled at $0.3^{\circ} \mathrm{C} \mathrm{min} \mathrm{m}^{-1}$ to $-40^{\circ} \mathrm{C}$ and then at $10^{\circ} \mathrm{C} \min ^{-1}$ to $-150^{\circ} \mathrm{C}$. The cryovials were transferred into liquid nitrogen $\left(-196^{\circ} \mathrm{C}\right)$ and stored for at least $24 \mathrm{~h}$.

The cryovials were warmed in air for $40 \mathrm{~s}$ and then immersed in water at $30-35^{\circ} \mathrm{C}$ until the ice melted $(2-3 \mathrm{~min})$. The ovaries were removed from the cryovials and placed in 1-2 $\mathrm{ml} \mathrm{M2}$ at room temperature for $5 \mathrm{~min}$, and then washed twice in $\mathrm{M} 2$ at room temperature ( $1-2 \mathrm{ml}$ per wash). After $5 \mathrm{~min}$, the ovaries were placed in $\mathrm{M} 2$ at $37^{\circ} \mathrm{C}$. The ovaries were either transplanted underneath the kidney capsules of recipient mice within 30 min of thawing or placed in Bouin's fixative for histology.

\section{Transfer to the kidney capsule}

Female B6CBF1 hybrid mice, 42 days old, were recipients for ovary grafts. Fresh and frozen ovaries were transferred unilaterally underneath the kidney capsules of the recipients as described previously (Candy et al., 1995a). Briefly, the left kidney of an anaesthetized recipient was exteriorized through an incision in the lumbar fossa. A small hole was torn in the kidney capsule and an ovary was inserted underneath the capsule. The kidney was replaced carefully and the recipient ovariectomized bilaterally. The recipients were autopsied 15 days after transplantation and the grafts and adjacent kidney tissue were dissected out and placed in Bouin's fixative for histology.

\section{Vaginal smears}

Vaginal smears were taken from the recipients every 1-2 days after transplantation. The vaginal wall of each recipient was scraped gently with a plastic probe and the cells smeared on to a clean glass slide. Smears were also taken from ovariectomized females. The air-dried smears were stained with an aqueous solution of $0.1 \%$ methylene blue. The stage of the oestrous cycle was determined from the cell types identified in the smear (Rugh, 1990).

\section{Histology}

Fixed tissues were embedded in paraffin wax, serially sectioned at $5 \mu \mathrm{m}$ and stained with haematoxylin and eosin. The tissue sections were coded and then examined 'blind' for the presence of follicles. Follicles were classified as follows: (1) primordial follicles with up to one layer of flattened granulosa cells surrounding the oocyte; (2) primary follicles with one or two layers of cuboidal granulosa cells; (3) preantral follicles with three or more layers of granulosa cells and no antrum; (4) antral follicles with an antral cavity; and (5) corpora lutea. Examples of the stages of follicles described are shown (Figs 1 and 2). Primordial follicles in which the oocyte was surrounded by a distinct membrane and primary follicles showing a dark nucleolus within the nucleus of the oocyte were counted in every fifth section in ovaries fixed immediately after collection and after freezing and thawing. In the grafted 10-day-old ovaries, which were generally larger than the ungrafted 10-day-old ovaries, and in the ungrafted adult ovaries, primordial follicles were counted in every tenth section. The total number of primordial follicles in each ovary was estimated by multiplying the number of follicles counted by five (ungrafted ovaries) or ten (grafted ovaries). Primary, preantral and antral follicles were counted in the section where the nucleolus was seen within the nucleus of the oocyte to avoid counting them more than once. Corpora lutea were scored at their maximum diameter. The number of corpora lutea corresponded closely to the number of ovulated oocytes found at the periphery of the grafts. Corpora lutea atretica were scored in the section where chromatin was seen within the oocyte. Each follicle was scored as either normal or damaged according to morphology. Normal follicles had intact granulosa cell layers, occasional isolated granulosa cells with pyknotic nuclei and unfragmented oocytes with a germinal vesicle. Damaged follicles had disrupted granulosa cell layers, large areas of granulosa cells containing pyknotic nuclei or oocytes that were degenerating or undergoing premature meiotic maturation (Tsafriri and Braw, 1984). Examples of normal and damaged follicles are shown (Figs 1 and 2). 

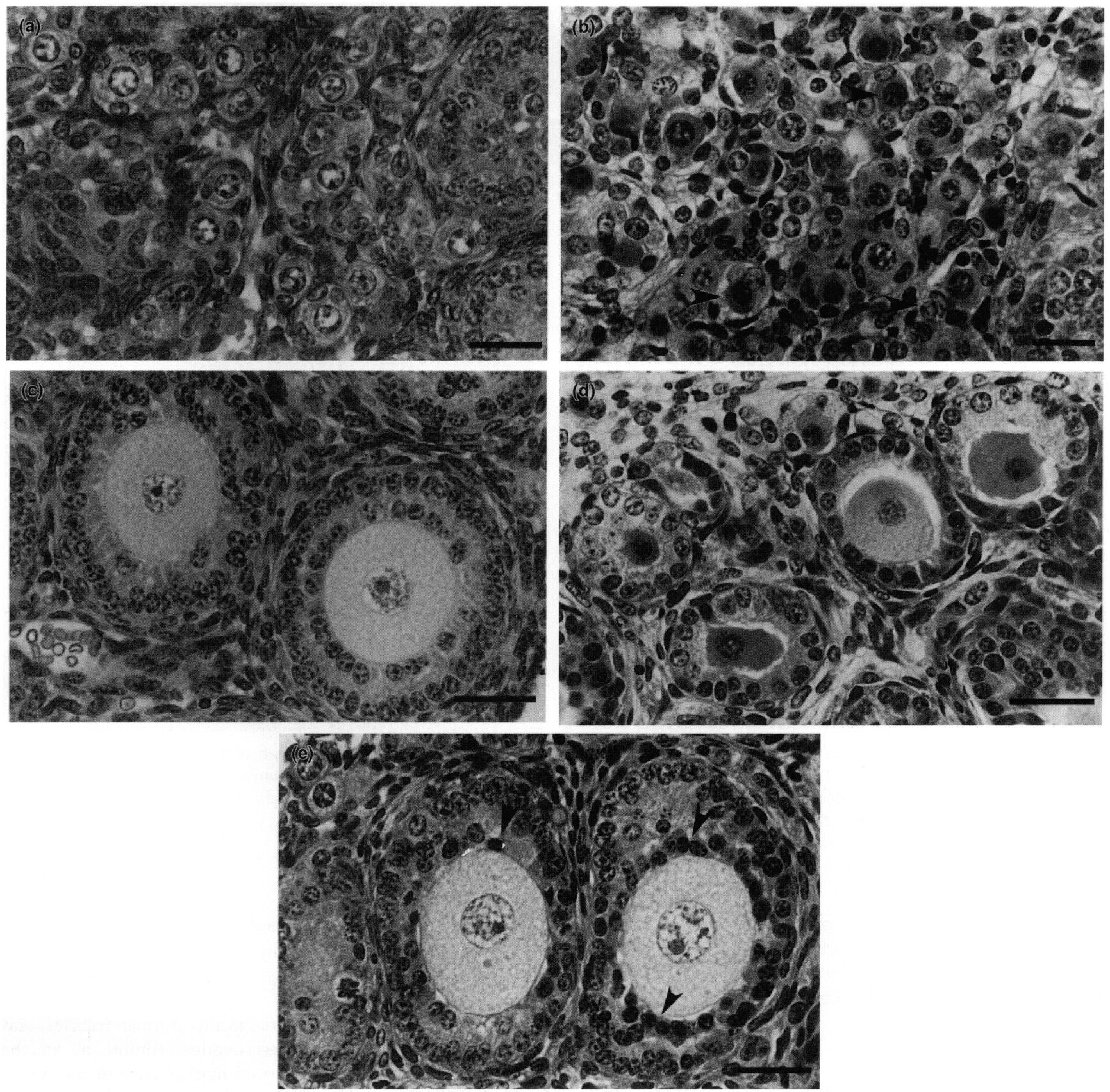

Fig. 1. Examples of follicles in fresh and frozen 10-day-old mouse ovaries. (a) Normal primordial follicles in fresh ovary. (b) Damaged primordial follicles containing pyknotic nucke (arrowheads) in an ovary frozen in glycerol. (c) Normal primary follicles in fresh ovary. (d) Damaged primary follicles in an ovary frozen in glycerol. Note the pyknotic nuclei in oocytes and granulosa cells. (e) Primary follicles in an ovary frozen in dimethylsulfoxide with apparently normal oocytes but surrounded by normal and pyknotic (arrowheads) granulosa cells. Scale bars represent $20 \mu \mathrm{m}$.

Experimental design

Ovaries from 10-day-old animals were used in this study because the population of follicles is homogeneous (approximately $95 \%$ are primordial follicles) and the intact ovaries can be grafted under the kidney capsule. Ovaries from groups of eight animals were collected on six separate days. In total, six-eight ovaries were frozen in cach treatment group. Fresh control ovaries from five of the six pools of ovaries were fixed immediately for histology. Ovaries were transferred into ovariectomized recipients on six separate occasions. On the days of transfer, about half of the thawed ovarics from a treatment group were fixed immediately for histology and the remainder was transferred. Three-four ovaries were fixed for histology from each treatment group and three-five ovaries per treatment group were transplanted. Two freshly collected, 10-day-old ovaries were transferred into ovariectomized recipients on each day of transfer, to act as controls. In 

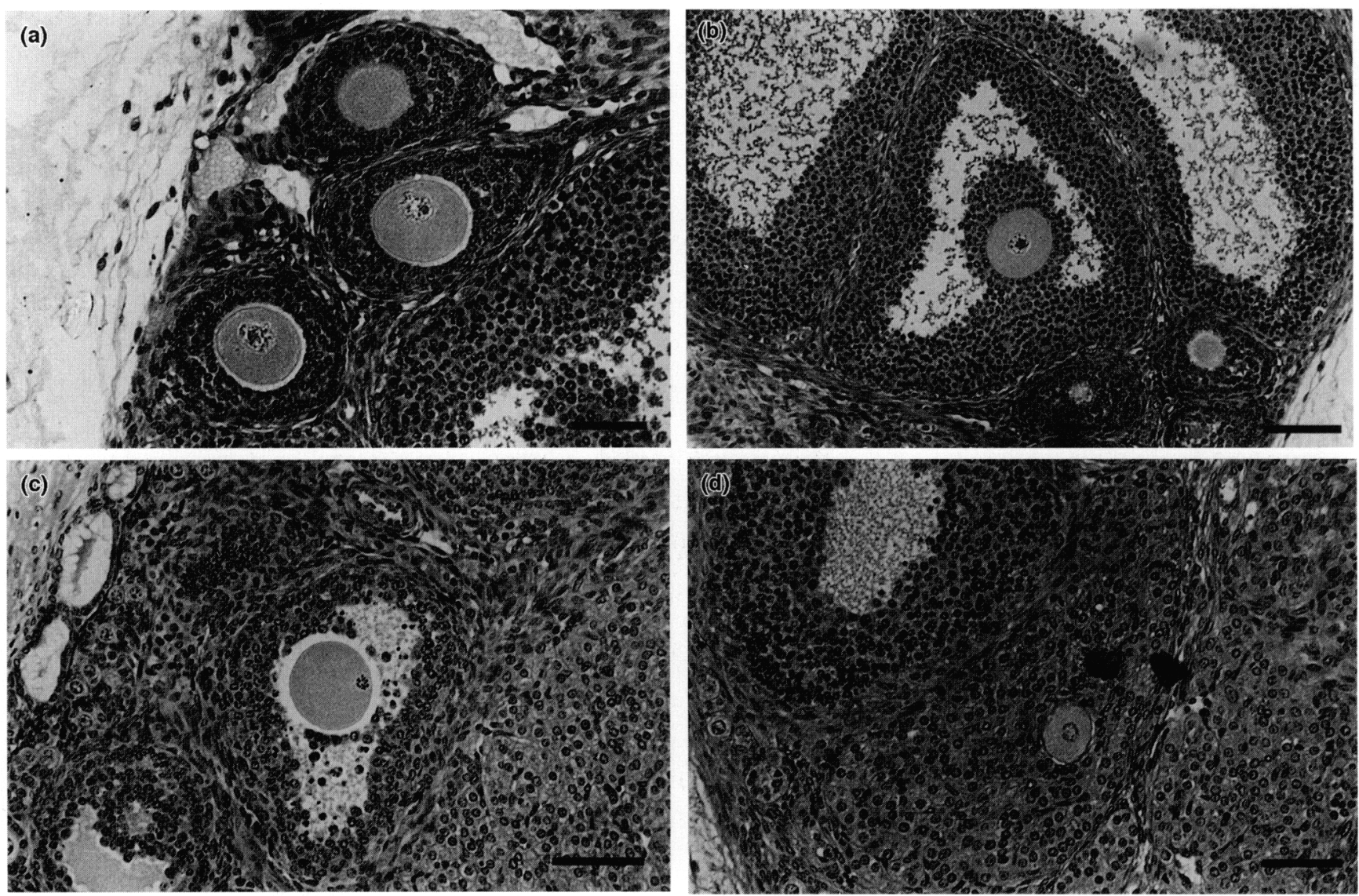

Fig. 2. Examples of follicles in grafts of fresh and frozen mouse ovaries. (a) Normal preantral follicles in a graft of fresh ovary. (b) Normal antral follicle in a graft of fresh ovary. (c) An atretic antral follicle containing an oocyte undergoing premature maturation in a graft of an ovary frozen in dimethylsulfoxide (DMSO). Note the metaphase chromosomes within the oocyte, the lack of cumulus cells surrounding the oocyte and the pyknotic granulosa cells floating in the antrum. (d) A corpus luteum atreticum in a graft of ovary frozen in DMSO. Scale bars in (a), (c) and (d) represent $50 \mu \mathrm{m}$, and the scale bar in (b) represents $80 \mu \mathrm{m}$.

addition, two animals were ovariectomized but did not receive grafts to control for artificial stimulation of vaginal cornification by repeated smearing. Ovaries from three intact ungrafted aduit females were fixed for comparison with grafts.

\section{Statistical analysis}

All results are expressed as means \pm SEM. Chi-squared test with Yates' correction for small samples was used to compare the proportion of ovaries that became established grafts. A one-way analysis of variance for unequally sized groups (Armitage and Berry, 1987) was used to compare (1) the percentage of normal follicles in fresh and frozen ovaries, transformed using arcsin of the square root, (2) the number of follicles present in grafts of fresh and frozen ovaries, transformed using $\log _{10}$ and (3) the interval between grafting and the first appearance of cornification. Differences between groups were compared using Gabriel's test (Kendall and Stuart, 1968). Treatments were considered significantly different when $P<0.01$.

\section{Results}

\section{Survival of follicles after thawing}

The proportion of morphologically normal follicles was calculated in fresh and frozen ovaries. Almost all of the primordial follicles $(99 \%)$ appeared normal in fresh ovaries. A high proportion of primordial follicles (8I-94\%) appeared normal in ovaries frozen in PROH, DMSO and EG (Table 1). However, irrespective of the time of exposure to the cryoprotectants before cooling, all ovaries contained significantly fewer morphologically normal primordial follicles than the fresh ovaries (PROH: $F_{\mid 4,121}=20.83, \quad P<0.0001 ;$ DMSO: $\left.F_{|4,12|}=21.32, \quad P<0.0001 ; \quad E G: \quad F_{|4,12|}=27.99, \quad P<0.0001\right)$. Ovaries frozen in GLY contained less than $29 \%$ normal primordial follicles $\left(F_{|4,13|}=91.3, P<0.0001\right)$. The time of exposure to the cryoprotectant appeared to have no effect on the percentage of normal primordial follicles in ovaries frozen in $\mathrm{PROH}\left(F_{|3,8|}=1.06, P=0.42\right)$ and DMSO $\left(F_{|3.8|}=1.33\right.$, $P=0.33$ ). Ovaries frozen in $E G$ after equilibration for $60 \mathrm{~min}$ appeared to have fewer normal primordial follicles than those equilibrated for a shorter time $\left(F_{|3,8|}=7.23, P=0.012\right)$. In addition, ovaries frozen in GLY after equilibration for $5 \mathrm{~min}$ 
Table 1. The effect of duration of exposure to cryoprotectants before cooling on the survival of primordial follicles in frozen mouse ovaries

\begin{tabular}{|c|c|c|c|c|}
\hline \multirow{3}{*}{$\begin{array}{l}\text { Time of } \\
\text { exposure } \\
\text { (min) }\end{array}$} & \multicolumn{4}{|c|}{$\begin{array}{c}\text { Mean number ( } \pm \text { SEM) of morphologically normal primordial follicles } \\
\text { as a percentage of the total number of primordial follicles }\end{array}$} \\
\hline & \multicolumn{4}{|c|}{ Cryoprotectant } \\
\hline & $\begin{array}{l}\text { Glycerol } \\
\text { (GLY) }\end{array}$ & $\begin{array}{l}\text { 1,2-Propanediol } \\
\text { (PROH) }\end{array}$ & $\begin{array}{l}\text { Dimethylsulfoxide } \\
\text { (DMSO) }\end{array}$ & $\begin{array}{l}\text { Ethanediol } \\
\quad \text { (EG) }\end{array}$ \\
\hline 5 & $\begin{array}{c}4.3 \pm 1.3^{\mathrm{abc}} \\
(n=3)\end{array}$ & $\begin{array}{c}84.3 \pm 3.7^{\mathrm{a}} \\
(n=3)\end{array}$ & $\begin{array}{c}89.3 \pm 1.2^{a} \\
\quad(n=3)\end{array}$ & $\begin{array}{c}94.3 \pm 1.2^{\mathrm{a}} \\
(n=3)\end{array}$ \\
\hline 12 & $\begin{array}{c}18.7 \pm 1.8^{\mathrm{ac}} \\
(n=3)\end{array}$ & $\begin{array}{c}84.0 \pm 3.1^{\mathrm{a}} \\
(n=3)\end{array}$ & $\begin{array}{c}81.3 \pm 1.2^{a} \\
\quad(n=3)\end{array}$ & $\begin{array}{c}92.0 \pm 1.5^{\mathrm{a}} \\
(n=3)\end{array}$ \\
\hline 30 & $\begin{array}{c}28.3 \pm 9.8^{\mathrm{ac}} \\
(n=3)\end{array}$ & $\begin{array}{c}82.3 \pm 3.5^{\mathrm{a}} \\
(n=3)\end{array}$ & $\begin{array}{c}82.7 \pm 1.2^{\mathrm{a}} \\
\quad(n=3)\end{array}$ & $\begin{array}{c}88.0 \pm 1.0^{\mathrm{a}} \\
(n=3)\end{array}$ \\
\hline 60 & $\begin{array}{c}25.0 \pm 4.4^{\mathrm{ac}} \\
(n=4)\end{array}$ & $\begin{array}{c}89.3 \pm 1.8^{a} \\
(n=3)\end{array}$ & $\begin{array}{c}82.3 \pm 2.4^{a} \\
(n=3)\end{array}$ & $\begin{array}{c}82.3 \pm 3.3^{\text {at }} \\
(n=3)\end{array}$ \\
\hline Freshly collected ovaries & $\begin{array}{c}99.0 \pm 0.2 \\
(n=5)\end{array}$ & & & \\
\hline
\end{tabular}

Superscript letters denote the following differences: a different from fresh ovaries, $P<0.01$; ${ }^{b}$ different within the same cryoprotectant treatment, $P<0.05$; 'different within the same equilibration times, $P<0.01$.

$n$, number of ovaries.

Table 2. The effect of duration of exposure to cryoprotectants before cooling on the survival of primary follicles in frozen mouse ovaries

Mean number ( \pm SEM) of morphologically normal primary follicles as a percentage of the total number of primary follicles

\begin{tabular}{|c|c|c|c|c|}
\hline \multirow{3}{*}{$\begin{array}{l}\text { Time of } \\
\text { exposure } \\
\text { (min) }\end{array}$} & & & & \\
\hline & \multicolumn{4}{|c|}{ Cryoprotectant } \\
\hline & $\begin{array}{l}\text { Glycerol } \\
\text { (GLY) }\end{array}$ & $\begin{array}{l}\text { 1,2-Propanediol } \\
\text { (PROH) }\end{array}$ & $\begin{array}{l}\text { Dimethylsulfoxide } \\
\text { (DMSO) }\end{array}$ & $\begin{array}{l}\text { Ethanediol } \\
\text { (EG) }\end{array}$ \\
\hline 5 & $\begin{array}{c}21.7 \pm 4.8^{\mathrm{a}} \\
\quad(n=3)\end{array}$ & $\begin{array}{c}34.3 \pm 3.5^{\mathrm{a}} \\
(n=3)\end{array}$ & $\begin{array}{c}40.7 \pm 8.4^{a} \\
\quad(n=3)\end{array}$ & $\begin{array}{l}40 \pm 3.2 \\
(n=3)\end{array}$ \\
\hline 12 & $\begin{array}{c}16.3 \pm 6.2^{\mathrm{a}} \\
(n=3)\end{array}$ & $\begin{array}{c}33.0 \pm 8.4^{\mathrm{a}} \\
(n=3)\end{array}$ & $\begin{array}{c}37.0 \pm 11.2^{\mathrm{a}} \\
(n=3)\end{array}$ & $\begin{array}{r}32.0 \pm 4^{a} \\
(n=3)\end{array}$ \\
\hline 30 & $\begin{array}{c}32.0 \pm 4.5^{\mathrm{a}} \\
(n=3)\end{array}$ & $\begin{array}{c}37.0 \pm 8.1^{\mathrm{a}} \\
(n=3)\end{array}$ & $\begin{array}{l}48.3 \pm 2.2^{\mathrm{a}} \\
\quad(n=3)\end{array}$ & $\begin{array}{c}30.7 \pm 7.3^{\circ} \\
(n=3)\end{array}$ \\
\hline 60 & $\begin{array}{c}29.3 \pm 7.1^{a} \\
(n=4)\end{array}$ & $\begin{array}{c}45.0 \pm 5.3^{\mathrm{a}} \\
(n=3)\end{array}$ & $\begin{array}{c}36.3 \pm 3.8^{a} \\
(n=3)\end{array}$ & $\begin{array}{c}27.0 \pm 10^{\mathrm{a}} \\
(n=3)\end{array}$ \\
\hline Freshly collected ovaries & $\begin{array}{r}91.0 \pm 1 \\
(n=5)\end{array}$ & & & \\
\hline
\end{tabular}

${ }^{2}$ Different from fresh ovaries, $p<0.01$.

$n$, number of ovaries.

contained fewer normal primordial follicles compared with the number recorded after longer equilibration times $\left(F_{[3,9]}=6.23\right.$, $P=0.014$ ). The percentage of normal primordial follicles in the ovaries frozen in the four different cryoprotectants was compared for each equilibration time. Ovaries frozen in GLY contained fewer normal primordial follicles at each equilibration time (5 min: $F_{[3,8]}=247.41, P<0.0001 ; 12 \mathrm{~min}: F_{[3,8]}=63.61$, $P<0.0001 ; \quad 30 \mathrm{~min}: \quad F_{[3,8]}=27.33, \quad P<0.0001 ; \quad 60 \mathrm{~min}$ : $\left.F_{[3,9]}=64.82, P<0.0001\right)$. In fresh ovaries, $91 \%$ of primary follicles appeared to be normal. Frozen ovaries all contained significantly fewer morphologically normal primary follicles $\left(16-48 \% ; F_{|16.37|}=9.61, P<0.0001\right.$, Table 2). There was no significant effect due to the type of cryoprotectant used or to the time of exposure to the cryoprotectants before cooling.

\section{Survival after grafting}

Similar proportions of fresh and frozen ovaries were recovered 15 days after transplantation underneath the kidney capsules of ovariectomized recipients (fresh: 92\%, $n=12$; frozen: $\left.90 \%, n=62 ; \chi_{[1]}^{2}=0.15, P=0.7\right)$. Three grafts, one 
Table 3. The effect of duration of exposure to cryoprotectants on the number of follicles in frozen mouse ovaries 15 days after grafting beneath the kidney capsules of ovariectomized recipients

\begin{tabular}{|c|c|c|c|c|}
\hline \multirow{3}{*}{$\begin{array}{l}\text { Time of } \\
\text { exposure } \\
\text { (min) }\end{array}$} & \multicolumn{4}{|c|}{ Mean number $( \pm$ SEM) of follicles } \\
\hline & \multicolumn{4}{|c|}{ Cryoprotectant } \\
\hline & $\begin{array}{l}\text { Glycerol } \\
\text { (GLY) }\end{array}$ & $\begin{array}{c}\text { 1,2-Propanediol } \\
(\mathrm{PROH})\end{array}$ & $\begin{array}{l}\text { Dimethylsulfoxide } \\
\text { (DMSO) }\end{array}$ & $\begin{array}{l}\text { Ethanediol } \\
\quad(E G)\end{array}$ \\
\hline 5 & $\begin{array}{c}107 \pm 45^{\text {ace }} \\
(n=3)\end{array}$ & $\begin{array}{c}1425 \pm 42 \\
(n=3)\end{array}$ & $\begin{array}{c}2599 \pm 27 \\
(n=2)\end{array}$ & $\begin{array}{c}1583 \pm 246 \\
(n=3)\end{array}$ \\
\hline 12 & $\begin{array}{c}646 \pm 218^{\text {af }} \\
(n=3)\end{array}$ & $\begin{array}{c}1942 \pm 464 \\
(n=3)\end{array}$ & $\begin{array}{c}1796 \pm 362 \\
(n=3)\end{array}$ & $\begin{array}{c}2036 \pm 329 \\
(n=3)\end{array}$ \\
\hline 30 & $\begin{array}{c}1221 \pm 141^{\mathrm{a}} \\
(n=3)\end{array}$ & $\begin{array}{c}1659 \pm 246 \\
(n=3)\end{array}$ & $\begin{array}{c}1619 \pm 383 \\
(n=3)\end{array}$ & $\begin{array}{c}1283 \pm 27^{\mathrm{b}} \\
(n=3)\end{array}$ \\
\hline 60 & $\begin{array}{c}1003 \pm 170^{a} \\
(n=4)\end{array}$ & $\begin{array}{c}1777 \pm 381 \\
(n=3)\end{array}$ & $\begin{array}{c}1616 \pm 540 \\
(n=3)\end{array}$ & $\begin{array}{c}841 \pm 83^{\text {ad }} \\
(n=3)\end{array}$ \\
\hline Fresh ovary & $\begin{array}{r}2534 \pm 327 \\
(n=10)\end{array}$ & & & \\
\hline
\end{tabular}

Superscript letters denote the following significant differences: different from fresh ovaries, ${ }^{a} P<0.01$, ${ }^{b} p<0.05$; different within the same cryoprotectant treatment, ${ }^{c} P<0.01$, ${ }^{d} P<0.05$; different within the same equilibration times, ${ }^{\mathrm{e}} P<0.01,{ }^{\mathrm{f}} P<0.05$.

$n$, number of ovaries.

fresh ovary and two ovaries frozen in DMSO, appeared to be resorbing and contained only a few follicles, most of which were atretic. These grafts were not included in the subsequent analysis of number of follicles.

\section{Number of follicles in grafts}

The total number of follicles in each graft was calculated (Table 3). Grafts of fresh ovaries and ovaries frozen in $\mathrm{PROH}$ and DMSO contained similar numbers of follicles $(\mathrm{PROH}$ : $F_{[4,17]}=1.68, P=0.2$; DMSO: $\left.F_{[4,16]}=1.6, \quad P=0.22\right)$. Equilibration time before cooling did not affect the number of follicles in grafts of ovaries frozen in $\mathrm{PROH}\left(F_{[3,8]}=0.29\right.$, $P=0.83)$ and DMSO $\left(F_{[3.7\}}=0.88, P=0.49\right)$. The number of follicles in grafts of ovaries frozen after equilibration in EG for 5,12 and $30 \mathrm{~min}$ was not significantly different from that in grafts of fresh ovaries. Grafts of ovaries frozen after $60 \mathrm{~min}$ equilibration with EG contained significantly fewer follicles than grafts of fresh ovaries $\left(F_{[4,17]}=7.28, P=0.001\right)$ and compared with the shorter equilibration times $\left(F_{[3,8]}=7.29\right.$, $P=0.011$ ). The grafts of ovaries frozen in GLY contained significantly fewer follicles than fresh ovaries irrespective of the equilibration time $\left(F_{[4,18]}=27.57, P<0.0001\right)$. Grafts of ovaries frozen after $5 \mathrm{~min}$ equilibration in GLY contained fewer follicles than those equilibrated for 12,30 and $60 \mathrm{~min}$ $\left(F_{[3,9]}=13.32, P=0.0012\right)$. The number of follicles in grafts frozen in the four different cryoprotectants was compared for each equilibration time. Grafts of ovaries frozen in GLY contained fewer follicles after 5 min equilibration $\left(F_{[3,7]}=29.12\right.$, $P=0.0003$ ) but no significant differences were observed between equilibration times of 12,30 and $60 \mathrm{~min}$ ( $12 \mathrm{~min}$ : $F_{[3,8]}=4.23, P=0.046 ; 30 \mathrm{~min}: F_{[3,8]}=0.74, P=0.56 ; 60 \mathrm{~min}$ : $\left.F_{[3,8]}=1.25, P=0.35\right)$.

The number of follicles present in the ovarian grafts was expressed as a proportion of the number of follicles present in
Table 4. The proportion of follicles in frozen mouse ovaries 15 days after grafting beneath the kidney capsules of ovariectomized recipients as a percentage of the total number of follicles in ungrafted ovaries from 10-day-old mice

\begin{tabular}{lcc}
\hline Cryoprotectant & $\begin{array}{c}\text { Number of } \\
\text { ovaries }\end{array}$ & $\begin{array}{c}\text { Mean \% } \\
\text { (士 SEM) of follicles in grafts }\end{array}$ \\
\hline Glycerol (GLY) & 13 & $19.7 \pm 3.5^{\mathrm{a}}$ \\
1,2-Propanediol (PROH) & 12 & $42.8 \pm 3.8^{\mathrm{b}}$ \\
Dimethylsulfoxide (DMSO) & 11 & $46.4 \pm 5.3$ \\
Ethanediol (EG) & 12 & $36.1 \pm 4.0^{\mathrm{a}}$ \\
Fresh ovary & 10 & $63.0 \pm 8.8$ \\
\hline
\end{tabular}

Superscript letters denote significant differences from fresh ovaries: ${ }^{\mathrm{a}} \mathrm{P}<0.01$, ${ }^{\mathrm{b}} \mathrm{P}<0.05$.

the ungrafted 10-day-old ovaries $(3974 \pm 123, n=54)$ (Table 4). Grafts of fresh ovaries contained $63 \%$ of the follicles counted in ungrafted 10-day-old ovaries. The proportion of follicles remaining in grafts of ovaries frozen in $\mathrm{PROH}$ and DMSO was not significantly different from that in grafts of fresh ovaries (PROH: $F_{[1,20]}=5.95, P=0.024 ;$ DMSO: $\left.F_{[1,19]}=3.54, P=0.075\right)$. Grafts of ovaries frozen in GLY and EG contained significantly fewer follicles than grafts of fresh ovaries (GLY: $F_{[1,21]}=24.74, P<0.0001 ; \quad E G: F_{[1,20]}=9.62$, $P=0.006)$.

\section{Development of the grafted ovaries}

Established grafts of fresh and frozen 10-day-old ovaries were morphologically similar. Grafts contained follicles at all stages of folliculogenesis. Between $93 \%$ and $97 \%$ of all follicles appeared morphologically normal. Approximately $90 \%$ of the total follicle population comprised primordial follicles in all 
grafts except those of ovaries frozen in GLY, which appeared to contain fewer primordial follicles $\left(75 \% ; \quad F_{14.531}=7.39\right.$, $P<0.01)$. The grafts contained $12.3 \pm 0.8$ large antral follicles, corpora lutea atretica or corpora lutea with ovulated oocytes close to the graft. There was no difference in the number of large antral follicles and corpora lutea between grafts of fresh and frozen ovaries $\left(F_{|4,53|}=0.5, P=0.74\right)$. By comparison, in freshly collected ovaries from adult animals, primordial follicles comprised $87 \%$ of the follicle population. Approximately $95 \%$ of the total follicle population appeared morphologically normal. Fresh adult ovaries contained $17.7 \pm 2.3$ large antral follicles, corpora lutea or corpora lutea atretica. Grafts of fresh and frozen 10-day-old ovaries appeared to contain more corpora lutea atretica than did freshly collected adult ovaries.

\section{Vaginal cornification}

Vaginal smears were taken from all recipients and examined for the presence of cornified epithelial cells, which are indicative of oestrogenic activity. A cornified smear was seen within 15 days of grafting in $91 \%(n=11)$ of the ovariectomized recipients of fresh ovaries and $96 \%(n=56)$ of recipients of frozen ovaries. The time from grafting to the time of the first cornified smear was similar in recipients of fresh (11.6 \pm 0.9 days) and frozen (11.4 \pm 0.7 days) ovaries. No significant difference was seen between the different cryoprotectant treatments $\left(F_{[4,59]}=0.91, P=0.46\right)$ or between the times of equilibration with each cryoprotectant (GLY: $F_{[3,8]}=1.77$, $P=0.23 ; \quad$ EG: $\quad F_{[3,12]}=2.48, \quad P=0.11 ; \quad \mathrm{PROH}: \quad F_{[3,9]}=1.31$, $P=0.33 ; \quad$ DMSO: $\left.\quad F_{[3,9]}=0.58, \quad P=0.64\right)$. None of the ungrafted ovariectomized females $(n=11$; one female died postoperatively) showed any evidence of vaginal cornification.

\section{Discussion}

In this study, mouse ovaries were cryopreserved successfully in $\mathrm{PROH}, \mathrm{DMSO}$ or EG. The majority of primordial follicles appeared morphologically normal after freezing and thawing and similar numbers of follicles remained in heterotopic grafts of fresh and frozen ovaries 15 days after transplantation. In contrast, ovaries cryopreserved in GLY contained fewer normal primordial follicles immediately after thawing and fewer follicles after grafting. These findings are consistent with previous observations. Few $(<10 \%)$ follicles survived in rat and mouse ovarian tissue frozen in GLY (Green et al., 1956; Deanesly, 1957). In marmoset ovarian tissue frozen in DMSO, 33\% of follicles appeared normal after thawing and large antral follicles developed in tissue grafted into nude mice (Candy et al., 1995a). Live births have been reported after orthotopic transplantation of mouse ovarian tissue frozen in GLY (Parrott, 1960) and DMSO (Cox et al., 1996) and sheep ovarian tissue frozen using DMSO (Gosden et al., 1994).

Successful freezing procedures rely on the removal of intracellular water to avoid the lethal effects of the formation of large amounts of intracellular ice during cooling or warming. Cryoprotectants are used to remove and/or substitute for the intracellular water before freezing begins. The ability of cryoprotectants to permeate cell membranes varies and thus affects the concentration of cryoprotectant that can penetrate a cell and the rate of permeation in and out of the cell. The location of a follicle within the tissue may also influence the extent of permeation. We compared the survival of follicles in ovaries frozen in four commonly used cryoprotectants: DMSO, PROH, EG and GLY. Freezing decreased the proportion of morphologically normal primordial follicles, although in ovaries frozen in DMSO, EG and PROH more than $80 \%$ survived. In contrast, $<50 \%$ of primary follicles survived freezing and thawing regardless of the cryoprotectant used. Primary follicles are located more centrally within the ovary than primordial follicles. Thus, the lower survival of primary follicles in pieces of ovarian tissue may reflect (1) the inability of the cryoprotectant to permeate to the centre of the tissue, (2) restriction of the movement of intracellular water during cooling and warming, or (3) difficulty in removing the cryoprotectant after thawing or a combination of these factors. Alternatively, cell permeabilities may change as the follicles develop; for example, the number of granulosa cell layers increases, the thecal layer differentiates, cell-cell communications become more complex. Isolated primordial and primary follicles frozen in $1.5 \mathrm{~mol}$ DMSO $1^{-1}$ survived equally well (primordial: $80 \%$ (Carroll and Gosden, 1993); primary: 78\% (Carroll et al., 1990)), suggesting that the location of follicles within the tissue may be important. However, it is possible that treatment with collagenase during the isolation of the follicles modified membrane permeability or cell-cell communication. Gosden et al. (1993) suggest that enzymatic digestion of follicles removes the thecal layer and basement membrane.

The time of exposure to the cryoprotectant before cooling must be long enough to achieve adequate permeation by the cryoprotectant without incurring toxic damage or rendering the cells vulnerable to excessive volume changes during the return to isotonic conditions after thawing (Mazur, 1981). The high degree of survival of primordial follicles in ovaries frozen in DMSO, PROH and EG after exposure to the cryoprotectant for only $5 \mathrm{~min}$ suggests that either these cryoprotectants penetrate the cells of ovarian tissue very rapidly or that full penetration of the cells is not necessary. Longer equilibration (12-60 min) with GLY increased survival, perhaps reflecting slower permeation into the cells. Isolated mouse oocytes are known to be less permeable to GLY than DMSO, PROH and EG (Jackowski et al, 1980; Paynter et al., 1995, 1996). The low permeability of cells to GLY may increase the risk of osmotic stress during thawing and dilution as water enters the cell more quickly than GLY is lost. This may explain the poor survival rate $(<30 \%)$ of primordial follicles in tissue frozen in GLY. Ovaries exposed to EG for $60 \mathrm{~min}$ before slow cooling contained fewer normal primordial follicles and subsequently fewer follicles in grafts, suggesting that this cryoprotectant is toxic when the tissue is exposed to it for prolonged periods before cooling.

The assessment of normality in follicles using morphological criteria is subjective. Oocytes containing degenerating (pyknotic) nuclear chromatin are obviously damaged. In contrast, apparently normal oocytes in follicles with some granulosa cells containing pyknotic nuclei are more difficult to classify. It is unknown how many granulosa cells must survive to ensure that a follicle is functional. As a more objective assay, fresh and frozen ovaries were transplanted under the kidney capsules of ovariectomized mice and survival was assessed by 
graft formation, the occurrence of vaginal cornification in the recipients and the number of follicles remaining 15 days after grafting. The proportion of grafts established from fresh ovaries and frozen ovaries, irrespective of the cryoprotectant, was similar and there was no difference in the time between grafting and observation of cornification of the vaginal epithelium in the ovariectomized recipients. Parkes (1957) also reported that in the mouse graft formation and the resumption of oestrogen secretion were similar with fresh ovaries and ovaries frozen in GLY. Using similar criteria, he concluded that GLY was a better cryoprotectant than PROH, EG and diethylene glycol for the cryopreservation of rat ovarian tissue (Parkes, 1958).

The number of follicles remaining in grafts of fresh and frozen ovaries 15 days after transplantation shows that the tissue is not damaged substantially by freezing in DMSO, $\mathrm{PROH}$ and EG (with the exception of ovaries frozen in EG after exposure to EG for $60 \mathrm{~min}$ ). Despite the poor survival rate of follicles in ovaries frozen in GLY, a greater proportion (about $25 \%)$ survived in this study than reported previously $(4 \%$, Green et al., 1956). The difference may be due to the rate of cooling $\left(0.3^{\circ} \mathrm{C} \mathrm{min}^{-1}\right.$ in this study compared with about $2.8^{\circ} \mathrm{C}$ $\min ^{-1}$ in the study by Green $e t$ al., 1956) or to the final storage temperature $\left(-196^{\circ} \mathrm{C}\right.$ versus $-79^{\circ} \mathrm{C}$, respectively). A slower rate of cooling minimizes the risk of intracellular freezing by allowing effective dehydration of the cell before the intracellular nucleation temperature is reached (Farrant, 1980). Damage can occur when cells are stored above the glass transition temperature (Farrant and Ashwood-Smith, 1980). Human ovarian tissue may also be better protected during freezing by DMSO, EG and PROH than by GLY (Newton et al., 1996). Ovaries might be frozen more successfully in GLY with slow, stepwise addition and removal of the cryoprotectant or by using an osmotic buffer such as sucrose to reduce osmotic stress (Leibo and Mazur, 1978), as reported for mature mouse oocytes (Fuller and Bernard, 1984) and mouse embryos (Rall and Wood, 1994).

No difference was found in the morphology of grafts of fresh ovaries and ovaries frozen in $\mathrm{PROH}, \mathrm{DMSO}$ or EG. The morphology of the grafts was very similar to that of ovaries recovered from adult $\mathrm{B} 6 \mathrm{CBF} 1$ mice. There was evidence of ovulation in both fresh and frozen grafts. Grafts contained more corpora lutea atretica compared with ungrafted adult ovaries. Deanesly (1956) suggested that the high incidence of corpora lutea atretica in subcutaneous grafts of rat ovarian tissue may reflect deficiencies in blood supply or the availability of gonadotrophins in heterotopic grafts or both factors.

The grafting process itself accounted for the majority of the follicular loss. Grafts of fresh ovaries contained only $63 \%$ of the follicles present in ovaries before transplantation. This confirms an earlier report (Green et al., 1956) in which only $59 \%$ of the follicles found in freshly collected ovaries remained in grafts after 2-30 days. The proportion of follicles in ovaries frozen in DMSO and PROH was similar to that in grafts of fresh ovaries (Table 4); significantly fewer follicles remained in grafts of ovaries frozen in EG or GLY. Although re-vascularization occurs within 3 days of grafting (Krohn, 1977), the central areas of many of the grafts were found to be necrotic. The use of vascular anastomoses improves the availability of oxygen during establishment of a graft in larger animals (Krohn, 1977), but this is impractical in the mouse. Transplantation of ovaries into the ovarian bursa of an ovariectomized recipient may be less damaging owing to the proximity of blood vessels.

In this study, we attempted to optimize the freezing procedure for ovarian tissue using systematic cryobiological principles. High proportions of primordial follicles survived freezing in DMSO, PROH and EG. Grafting rather than freezing and thawing caused the major loss of follicles. Overall, DMSO and PROH proved to be the most effective cryoprotectants for 10-day-old mouse ovaries.

The mammalian ovary contains a vast excess of follicles. It is possible that, despite the loss of follicles due to grafting, the pool of primordial follicles remaining in frozen ovarian tissue would support a normal reproductive lifespan.

The authors would like to thank I. Harragan for the preparation of the histology sections. This work was funded by the Medical Research Council.

\section{References}

Armitage P and Berry G (1987) Statistical Methods in Medical Research Blackwell, Oxford

Candy Cl, Wood MJ, Whittingham DG, Merriman JA and Choudhury N (1994) Cryopreservation of immature mouse oocytes Human Reproduction 9 $1738-1742$

Candy CJ, Wood MJ and Whittingham DG (1995a) Follicular development in cryopreserved marmoset ovarian tissue after transplantation Human Reproduction $102334-2338$

Candy CJ, Wood MJ and Whittingham DG (1995b) The effect of cryoprotectant on follicular survival in frozen-thawed mouse ovaries journal of Reproduction and Fertility Abstract Series 1550

Carroll J and Gosden RG (1993) Transplantation of frozen-thawed mouse primordial follicles Human Reproduction 8 1163-1167

Carroll J, Whittingham DG, Wood MJ, Telfer E and Gosden RG (1990) Extraovarian production of mature viable mouse oocytes from frozen primary follicles Journal of Reproduction and Fertility $90321-327$

Carroll J, Wood MJ and Whittingham DG (1993) Normal fertilization and development of frozen-thawed mouse oocytes: protective action of certain macromolecules Biology of Reproduction 48 606-612

Cox S-L, Shaw J and Jenkin G (1996) Transplantation of cryopreserved fetal ovarian tissue to adult recipients in mice Journal of Reproduction and Fertility $107315-322$

Deanesly R (1956) Cyclic function in ovarian grafts Journal of Endocrinology 13 211-220

Deanesly R (1957) Egg survival in immature rat ovaries grafted after freezing and thawing Proceedings of the Royal Society of London Series B 147 412-42I

Farrant J (1980) General observations on cell preservation. In Low Temperature Preservation in Medicine and Biology pp 1-18 Eds MJ Ashwood-Smith and J Farrant. Pitman Medical Limited, Kent

Farrant J and Ashwood-Smith M (1980) Practical aspects. In Low Temperature Preservation in Medicine and Biology pp 285-310 Eds MJ Ashwood-Smith and J Farrant. Pitman Medical Limited, Kent

Fuller BJ and Bernard A (1984) Successful in vitro fertilization of mouse oocytes after cryopreservation using glycerol Cryo-Letters 5 307-312

Gosden RG, Boland NI, Spears N, Murray AA, Chapman M, Wade JC, Zohdy NI and Brown N (1993) The biology and technology of follicular oocyte development in vitro. Reproductive Medical Review 2 129-152

Gosden RG, Baird DT, Wade JC and Webb R (1994) Restoration of fertility to oophorectomized sheep by ovarian autografts stored at $-196^{\circ} \mathrm{C}$ Human Reproduction 9 597-603

Green SH, Smith AU and Zuckerman S (1956) The numbers of oocytes in ovarian autografts after freezing and thawing Journal of Endocrinology 13 330-334

Grischenko VI, Demina LG, Chadayev VE, Lobintseva GS and Chub NN (1987) Accumulation and storage of cryopreserved human ovarian tissue for allogenic transplantation in obstetrics and gynecologic practice Kryobiologia 3 7-11 
Harp R, Leibach J, Black J, Keldahl C and Karow A (1994) Cryopreservation of murine ovarian tissue Cryobiology 31 336-343

Hovatta O, Silye R, Krausz T, Abir R, Margara R, Trew G, Lass A and Winston RML (1996) Cryopreservation of human ovarian tissue using dimethylsulphoxide and propanediol-sucrose as cryoprotectants Human Reproduction 11 1268-1272

Jackowski S, Leibo SP and Mazur P (1980) Glycerol permeabilities of fertilized and unfertilized mouse ova Journal of Experimental Zoology 212 329-341

Kendall MG and Stuart A (1968) The Advanced Theory of Statistics (Vol. 3, 2nd Edn) Griffin, London

Krohn PL (1977) Transplantation of the ovary. In The Ovary (Vol. II, 2nd Edn) pp 101-128 Eds S Zuckerman and BJ Weir. Academic Press, London

Leibo SP and Mazur P (1978) Preservation of mammalian embryos by freezing. In Methods in Mammalian Reproduction pp 179-201 Ed. JC Daniel, Jr Academic Press, London

Mazur P (1981) Fundamental cryobiology and the preservation of organs by freezing. In Organ Preservation for Transplantation (2nd Edn) pp 143-175 Eds AM Karow, Jr and DE Pegg. Marcel Dekker, New York

Newton H, Aubard Y, Rutherford A, Sharma V and Gosden R (1996) Low temperature storage and grafting of human ovarian tissue Human Reproduction 11 1487-1491

Parkes AS (1957) Viability of ovarian tissue after freezing Proceedings of the Royal Society of London Series B $147520-528$

Parkes AS (1958) Factors affecting the viability of frozen ovarian tissue Journal of Endocrinology 17 337-343
Parkes AS and Smith AU (1953) Regeneration of rat ovarian tissue grafted after exposure to low temperatures Proceedings of the Royal Society of London Series B $140455-470$

Parrott DMV (1960) The fertility of mice with orthotopic ovarian grafts derived from frozen tissue Journal of Reproduction and Fertility $1230-241$

Paynter SJ, Fuller BJ, McGrath JJ, Bernard AG and Shaw RW (1995) Cryoprotectant permeability of mammalian oocytes Cryobiology 32 575-576

Paynter SJ, Fuller BJ and Shaw RW (1996) Temperature dependence of K-K coefficients for mouse oocytes in the presence of ethylene glycol Cryobiology 33663

Rall WF and Wood MJ (1994) High in vitro and in vivo survival of day 3 mouse embryos vitrified or frozen in a non-toxic solution of glycerol and albumin Journal of Reproduction and Fertility 101 681-688

Rugh R (1990) The Mouse: Its Reproduction and Development Oxford University Press, Oxford

Tsafriri A and Braw RH (1984) Experimental approaches to atresia in mammals. In Oxford Review of Reproduction and Biology (Vol. 6) pp 226-265 Ed. JR Clarke. Oxford University Press, Oxford

Wood MJ, Whittingham DG and Rall WF (1987) The low temperature preservation of mouse oocytes and embryos. In Mammalian Development: $A$ Practical Approach pp 255-280 Ed. M Monk. IRL Press, Oxford

Wood MJ, Candy, CJ and Whittingham DG (1995) Effect of cryoprotectant and grafting on survival of frozen mouse ovary Cryobiology 32 573-574 